\title{
高速液体クロマトグラフィーによる養殖魚中 合成抗菌剤の定量法
}

\author{
(昭和 58 年 10 月 31 日受理)
}

堀 義 宏 ${ }^{* 1}$

\section{Determination of Synthetic Antibacterials in Cultured Fish by High Performance Liquid Chromatography}

\author{
Yoshihiro HoRI \\ (Hokkaido Institute of Public Health: Nishi 12-chome, Kita 19-jo, Kita-ku, Sapporo, \\ Hokkaido, Japan)
}

\begin{abstract}
A high performance liquid chromatographic method for determination of furazolidone, difurazone, sulfamonomethoxine and sulfadimethoxine in cultured fishes has been developed.

Synthetic antibacterials extracted from samples were adsorbed on an alumina column and were eluted with $20 \mathrm{ml}$ of $95 \%$ acetonitrile as fraction I (nitrofurans) and then with $30 \mathrm{ml}$ of $85 \%$ acetonitrile as fraction II (sulfa drugs). Each fraction was injected into an HPLC column packed with Nucleosil $5 \mathrm{C}_{18}$. Fractions I and II were eluted with acetonitrile-acetic acid-water $=70: 0.1: 30$ and 30:0.05:70, with detection at 380 and $272 \mathrm{~nm}$, respectively.

The recoveries of furazolidone, difurazone, sulfamonomethoxine and sulfadimethoxine were in the ranges of $95.5 \sim 99.7 \%, 84.0 \sim 90.0 \%, 96.7 \sim 101.3 \%$ and $95.3 \sim 99.0 \%$, respectively. The limit of detection of each drug was $0.03 \mathrm{ppm}$ in the test samples.
\end{abstract}

(Received October 31, 1983)

Key words: 高速液体クロマトグラフィー high performance liquid chromatography; 養殖魚 cultured fish; 合成抗菌剤 synthetic antibacterials; フラゾリドン furazolidone; ジフラゾン difurazone; スルファモノメトキシン sulfamonomethoxine; スルファジメトキシン sulfadimethoxine

\section{緒言}

水産用医薬品で使用基準が定められている合成抗菌剤 は 5 種類あり,これらは Table 1 亿示した養殖魚を対 象に飼料に添加して用いられている.

従来, これら合成抗菌剤の測定には，ガスクロマトグ ラフィー1) 3)，薄層クロマトグラフィー・デンシトメト リー2)が用いられてきた。近年，貫山ら ${ }^{4)}$ はサルファ剂

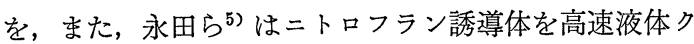
ロマトグラフィー（以下，HPLC と略す）を用いて測定 している.

\footnotetext{
*1 北海道立衛生研究所：札幌市北区北 19 条西 12 丁目
}

今回, 著者はフラゾリドン, ジフラゾン, スルファモ ノメトキシン，スルファジメトキシンの 4 種類を系統的 に分離し，HPLC を用いて定量する方法を検討したの で報告する。

\section{実験方法}

1. 試料

北海道内で養殖されているウナギ，コイ及びニジマス の筋肉部を用いた.

\section{2. 試薬}

アセトン, クロロホルム, アセトニトリル, メタノー ル，n-ヘキサン， $n$-プロパノール，塩化ナトリウム，眽 酸: 和光純薬工業 (株) 製特級

フラゾリドン：上野製薬 (株) 製 
Table 1. Drugs for Fish Restricted by Standard of Using

\begin{tabular}{ll}
\hline \hline \multicolumn{1}{c}{ Cultured fish } & \multicolumn{1}{c}{ Drug } \\
\hline Rainbow trout (Nijimasu) & Sulfamonomethoxine \\
\hline Sweet fish (Ayu) & $\begin{array}{l}\text { Sulfamonomethoxine } \\
\text { Furazolidone }\end{array}$ \\
\hline Carp (Koi) & Furazolidone \\
\hline Eel (Unagi) & Sulfamonomethoxine \\
& Sulfadimethoxine \\
& Furazolidone \\
\hline & Sulfamonomethoxine \\
Yellow tail (Buri) & Sulfadimethoxine \\
& Furazolidone \\
& Difurazone \\
& Thiamphenicol \\
\hline Red sea bream (Madai) & Furazolidone \\
\hline
\end{tabular}

Table 2. HPLC Conditions for Determination of Synthetic Antibacterials

\begin{tabular}{llc}
\hline \hline & Fraction I & Fraction II \\
\hline Column & $\begin{array}{l}\text { Nucleosil } \\
\text { acetonitrile-acetic acid-water }\end{array}$ \\
& \multicolumn{2}{c}{$(4 \mathrm{~mm}$ I.d. $\times 250 \mathrm{~mm})$} \\
Mobile phase & $70: 0.1: 30$ & $30: 0.05: 70$ \\
Flow rate & $0.8 \mathrm{ml} / \mathrm{min}$ & $0.9 \mathrm{ml} / \mathrm{min}$ \\
Detector & $380 \mathrm{~nm}$ & $272 \mathrm{~nm}$ \\
Sensitivity & $4 \times 10^{-2}$ AUFS & $8 \times 10^{-2}$ AUFS \\
Column temp. & $40^{\circ} \mathrm{C}$ \\
Chart speed & $5 \mathrm{~mm} / \mathrm{min}$ \\
Sample size & & $10 \mu 1$ \\
\hline
\end{tabular}

ジフラゾン：台糖ファイザー (株) 製

スルファモノメトキシン，スルファジメトキシン：富 士薬品工業 (株) 製

標準溶液：いずれも $10 \mathrm{mg}$ を精科し，フラゾリドン, スルファモノメトキシン, スルファジメトキシンはアセ トンに, ジフラゾンはメタノールに溶解し， $100 \mu \mathrm{g} / \mathrm{ml}$ の原液を作製し，原液をアセトンで適宜希釈して用い た.

アルミナカラム：塩基性活性度 I のカラムクロマトグ ラフ用アルミナ (Woelm 社製) $6 \mathrm{~g}$ を内径 $15 \mathrm{~mm}$, 長 さ $300 \mathrm{~mm}$ のガラス管にアセトニトリルを用いて詰め, アセトニトリル $20 \mathrm{ml}$, さらに $95 \%$ アセトニトリル 30 $\mathrm{ml}$ で順次洗浄した。

\section{4. 装置}

高速液体クロマトグラフ：(株) 島津製作所製 LC-4A 型

検出器：（株）島津製作所製紫外可視分光光度計検出器 SPD-1 型
分光光度計：(株) 島津製作所ダブルビーム分光光度計 UV-180

\section{HPLC の測定条件}

測定条件は, Table 2 に示した.

\section{6. 試験溶液の調製}

試料 $10 \mathrm{~g}$ をホモジナイザーカップにとり，アセトン $50 \mathrm{ml}$ を加え 5 分間ホモジナイズした後，桐山漏斗を用 いて吸引ろ過し，さらに残留物をアセトン $50 \mathrm{ml}$ で洗 いながらろ過する．万液に $n$-プロパノール $15 \mathrm{ml}$ を加 え，ロータリーエバポレーターを用い， $45^{\circ}$ の水浴で約 $15 \mathrm{ml}$ まで減圧濃縮する. 濃縮液を $100 \mathrm{ml}$ の分液漏斗 に移し，アセトン $20 \mathrm{ml}, n$-ヘキサン $30 \mathrm{ml}$ 及び $3 \%$ 塩 化ナトリウム溶液 $60 \mathrm{ml}$ を加え, 軽く振とうする. 上層 の $n$-ヘキサンを除去し, 再び $n$-ヘキサン $30 \mathrm{ml}$ を加え て激しく振とうする.下層を別の分液漏斗に移し，ク口 ロホルム $25 \mathrm{ml}$ を加え振とうした後, クロロホルム層 を分取し，100 ml のナス型フラスコにとる．これをさら に2 回繰返し，クロロホルム層を合し，ロータリーエバ ポレーターで約 $1 \mathrm{ml}$ まで濃縮する.濃縮液をアルミナ カラムに入れ，95\%アセトニトリル $20 \mathrm{ml}$ で溶出する (フラクション I).さらに $85 \%$ アセトニトリル $30 \mathrm{ml}$ で溶出する（フラクション II)。溶出液を減圧濃縮乾固 し, フラクションIはアセトニトリル-酢酸-水 $(70$ : $0.1: 30)$ 混液 $1 \mathrm{ml}$, フラクション II はアセトニトリルー 酢酸一水 $(30: 0.05: 70)$ 混液 $1 \mathrm{ml}$ 飞溶解し, Table 2 に 示した HPLC の測定条件下で，その $10 \mu 1$ を注入する.

以上, 試験操作の概略を Scheme 1 に示した.なお, 操作は, 褐色のガラス器具を用い, 遮光して行った.

\section{結果及び考察}

\section{HPLC 測定条件の検討}

\section{1 測定波長}

各薬剂を HPLC に用いた溶離液中で吸収スペクトル を測定したとき（Fig. 1)，フラゾリドンは $365 \mathrm{nm，ジ}$ フラゾンは $380 \mathrm{~nm}$, スルファモノメトキシンは $274 \mathrm{~nm}$ 及びスルファジメトキシンは $272 \mathrm{~nm}$ に吸收極大を示し た.この結果からみて一定波長による同時分析は不可能 なので測定波長をニトロフラン誘導体は $380 \mathrm{~nm}$, サル ファ剂は $272 \mathrm{~nm}$ に設定した.

\section{2 カラム及び溶離液}

カラムは Nucleosil $5 \mathrm{C}_{18}$ を用い，また，溶離液はア セトニトリルー水の組合せで検討した. フラクションI のニトロフラン誘導体については，フラゾリドンはアセ トニトリル濃度の増加につれ保持時間が短縮し，また， ジフラゾンは，アセトニトリルー水系に酢酸を添加する ことにより保持時間の短縮が見られた. 一方, フラクシ ョン II のサルファ剂は, フラクションI の溶離液では ニトロフラン誘導体に比べて溶出が早いため使用できな かった. また,アセトニトリルー水系のみでは各ピークの 分離能が悪いため, 酢酸を添加したところ, 分離能が高 


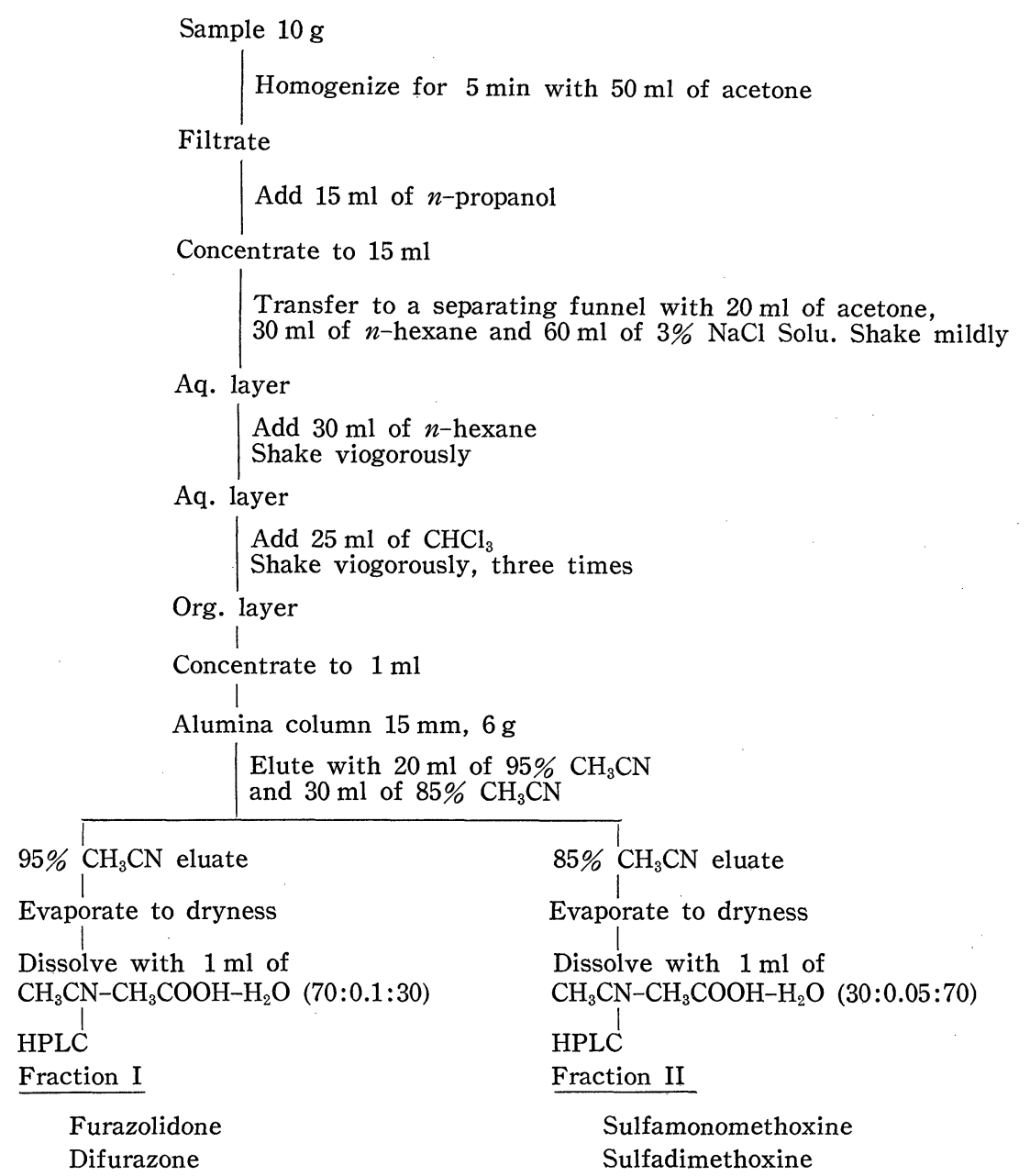

Scheme 1. Analytical procedure for synthetic antibacterials

くなり，かつ感度も上昇した.

以上の結果から，溶離液としてフラクションIは，ア セトニトリルー酢酸-水=70:0.1:30,フラクション II は 30:0.05:70を用いた. フラクション I 及び II の標準液 のクロマトグラムは Fig. 2-(A) 及び Fig. 3-(A) に示 すと括りで，いずれも10分以内に測定することがでさ た.

\section{2. 検量線及び検出限界}

各フラクションの標準溶液をそれぞれの薬剤として $0.25 \sim 10 \mu \mathrm{g}$ 相当量の範囲でとり乾固した後, 各溶離液 $1 \mathrm{ml}$ に溶解し, その $10 \mu 1$ を HPLC に注入し, ピーク 高さにより検量線を作成した. その結果, フラゾリドン は 2.5〜100 ng，また，他の薬剤は 5.0〜100 ng の範囲 で良好な直線性が得られた。な执，試料 $10 \mathrm{~g}$ を用いた 場合の検出限界はいずれも $0.03 \mathrm{ppm}$ であった。

\section{3. 試料からの抽出及びクリーンアップ}

\section{1 前処理}

脂肪が存在すると HPLC で測定する際，妨害物質に よる感度の低下，カラムの劣化などを招くので，あらか じめ脱脂する必要がある. 鶏肉及び䳕卵では, アセトニ トリル抽出液を $n$-ヘキサンで洗浄することにより脱脂 できたが6)，魚の場合，この操作では脱脂が不十分であ った. そこで今回, 試料から抗菌剤の抽出溶媒としてア セトンを用い, このアセトン抽出液を一旦濃縮し, 濃縮 液にアセトン及び $3 \%$ 塩化ナトリウム溶液を加え, $n$-ヘ キサンで 2 回洗浄後, クロロホルムで再抽出した. この 操作により，抗菌剤を損失することなく脱脂することが できた.

アセトン抽出液を濃縮する際, 泡立ちや突沸のため, 濃縮操作が困難であり, また, 回収率にバラッキが生じ た. 中澤らねはこれらを防止するため, 抽出液に $n$-プ 


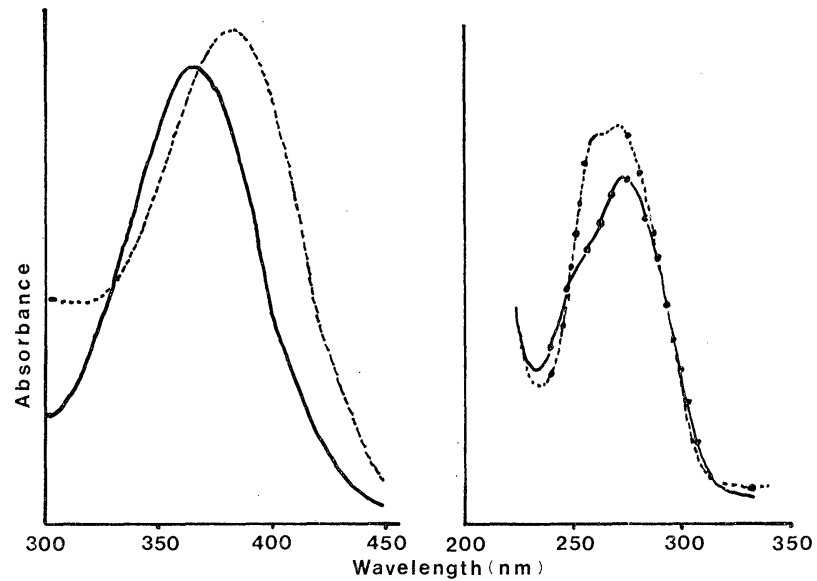

Fig. 1. Absorption spectra of synthetic antibacterials in mobile phase

-, furazolidone

, difurazone

-

-.-. sulfadimethoxine

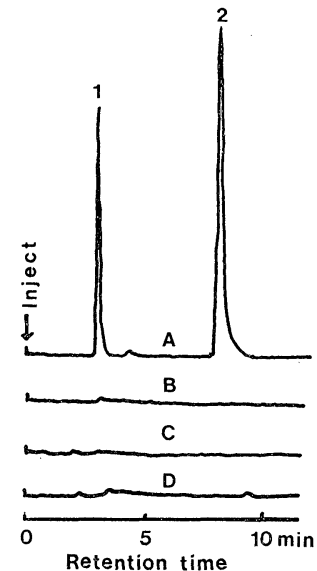

Fig. 2. Liquid chromatograms of fraction I A) mixed standard

1) furazolidone $(2.5 \mu \mathrm{g} / \mathrm{ml})$

2) difurazone $(5 \mu \mathrm{g} / \mathrm{ml})$

B) rainbow trout C) eel D) carp

ロパノールを添加した後濃縮する方法を用いている.ま た，脱脂後，クロロホルムで再抽出する際，n-プロパノ 一ル及びアセトン存在量により, 抗菌剤の回収率にバラ ツキが見られた。 そこで $n$-プロパノール及びアセトン の添加量について検討したところ，抽出液に $n$-プロパ ノール $15 \mathrm{ml}$ 添加後, 約 $15 \mathrm{ml}$ まで濃縮しアセトンを ほとんど留去した後，再びアセトン $20 \mathrm{ml}$ を加えク口 ロホルムで抽出した場合, 泡立ちもなく濃縮でき, かつ 回収率が最も良く、バラツキも少なかった。

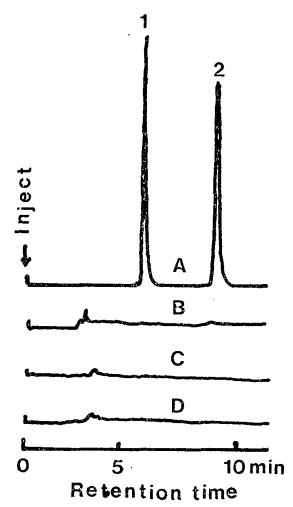

Fig. 3. Liquid chromatograms of fraction II A) mixed standard

1) sulfamonomethoxine $(5 \mu \mathrm{g} / \mathrm{ml})$

2) sulfadimethoxine $(5 \mu \mathrm{g} / \mathrm{ml})$

B) rainbow trout $C$ ) eel $D$ ) carp

\section{2 アルミナカラムからの溶出}

アルミナカラムによる不純物の除去及び薬剤の溶出条 件を検討した. 結果は Fig. 4 に示すよらに $95 \%$ アセト ニトリル $20 \mathrm{ml}$ でフラゾリドン及びジフラゾンが完全 に溶出し(フラクションI), さらに $85 \%$ アセトニトリ ル $30 \mathrm{ml}$ でスルファモノメトキシン及びスルファジメ トキシンが完全に溶出した（フラクション II)：このフ ラクションI及び II の HPLC のクロマトグラムは Fig. 2 (B, C, D) 及び Fig. 3 (B, C, D) に示すと和り で，いずれのフラクションについてもクロマトグラム上 に抗菌剤の妨害となる物質は見られず，ウナギ，コイ及 
Table 3. Recovery of Synthetic Antibacterials from Cultured Fishes

\begin{tabular}{|c|c|c|c|c|}
\hline \multirow{2}{*}{ Drug } & \multirow{2}{*}{$\begin{array}{c}\text { Added } \\
\mu \mathrm{g} / \mathrm{g}\end{array}$} & Eel & Carp & Rainbow trout \\
\hline & & \multicolumn{3}{|c|}{ Recovery* } \\
\hline \multirow{2}{*}{ Furazolidone } & 0.1 & $99.7 \pm 1.5$ & $97.7 \pm 2.1$ & $98.3 \pm 2.9$ \\
\hline & 0.5 & $98.2 \pm 3.1$ & $98.2 \pm 1.8$ & $95.5 \pm 0.87$ \\
\hline \multirow{2}{*}{ Difurazone } & 0.2 & $84.0 \pm 2.0$ & $89.3 \pm 1.4$ & $89.2 \pm 0.94$ \\
\hline & 1.0 & $90.0 \pm 2.0$ & $87.0 \pm 2.6$ & $89.0 \pm 1.0$ \\
\hline \multirow{2}{*}{ Sulfamonomethoxine } & 0.2 & $97.0 \pm 1.0$ & $101.3 \pm 1.2$ & $98.7 \pm 1.2$ \\
\hline & 1.0 & $98.3 \pm 0.58$ & $100.3 \pm 0.58$ & $96.7 \pm 1.4$ \\
\hline \multirow{2}{*}{ Sulfadimethoxine } & 0.2 & $95.3 \pm 1.5$ & $99.0 \pm 1.7$ & $95.7 \pm 1.2$ \\
\hline & 1.0 & $97.3 \pm 0.58$ & $98.8 \pm 1.3$ & $96.7 \pm 1.9$ \\
\hline
\end{tabular}

* Mean \pm S.D. for 3 samples
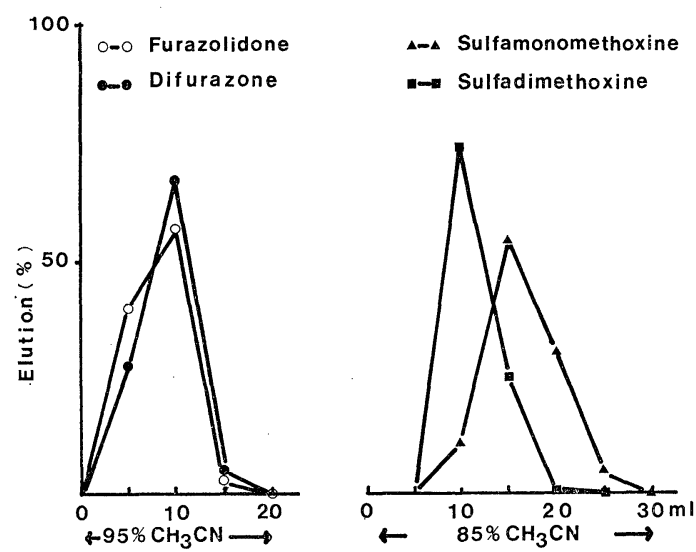

Fig. 4. Elution patterns of synthetic antibacterials from alumina column

びニジマスは同じ操作で前処理ができた。

\section{4. 添加回収実験}

本法による添加回収実験の結果については Table 3 に示すように，フラゾリドンは 95.5 99.7\%，ジフラゾ ンは 84.0〜90.0\%，スルファモノメトキシンは 96.7〜 101.3\%，スルファジメトキシンは 95.3〜99.0\%の回収 率が得られ，また，標準偏差も 0.58 3.1\%の範团で行 うことができた。なお，水産用医薬品で使用基準のある チアンフェニコールについて本法による測定を試みた が，チアンフェニコールの吸収極大が $226 \mathrm{~nm}$ 付近にあ り, $272 \mathrm{~nm}$ 及び $380 \mathrm{~nm}$ に吸収がないこと，また，226 $\mathrm{nm}$ で測定したとき，試料中の妨害物質により定量でき ないため本法から除外した。

\section{5. 養殖魚の残留試験}

本法により北海道内で養殖されている ジマス 4 検 体，ウナギ 3 検体，コイ 3 検体について残留量を測定し たが，4薬剤についてはいずれも定量範囲内において検 出されなかった。

\section{ま と め}

HPLC による養殖魚中フラゾリドン, ジフラゾン, ス ルファモノメトキシン及びスルファジメトキシンの定量 法を検討した.

アセトンで抽出, 脱脂後, クロロホルムで再抽出し, アルミナカラムにより 2 分画し，これを HPLC で定量 した. 本法による回収率は, フラゾリドン 95.5 99.7\% ジフラゾン 84.0〜90.0\%，スルファモノメトキシン 96. 7 101.3\%，スルファジメトキシン 95.3〜99.0\%で あり，また，検出限界はいずれも $0.03 \mathrm{ppm}$ であった.

文献

1) 厚生省環境衛生局乳肉衛生課：畜水産食品中の残 留物質検查法，第 2 集の 2 (1978).

2) 厚生省環境衛生局乳肉衛生課：同上. 第 2 集の 3 (1979).

3）厚生省環境衛生局乳肉衛生課：同上. 第 2 集の 4 4 (1981).

4) 貫山道子, 渡辺重信, 伊藤和敏：神奈川県衛生研 究所報, No. 11, 61〜62 (1981).

5) 永田知子, 宮本文夫，佐伯政信：食衛誌. 23,278 $\sim 282$ (1982).

6) 堀 義宏：同上, 24, 447 453 (1983).

7) 中澤裕之, 高畠英伍, 日野誠二, Canutte A. Mtema: 分析化学, 32, 179 183 (1983). 